\title{
Substituted flavones: a promising scaffold in the fight against malaria
}

\author{
Flore Nardella ${ }^{1,2^{*}}$, Valérie Collot ${ }^{3}$, Sylvia Stiebing ${ }^{3}$, Marcel Kaiser ${ }^{4}$, Martine Scmitt ${ }^{1}$, Ermanno Candolfi ${ }^{2}$, \\ Catherine Vonthron-Sénécheau ${ }^{1}$ \\ From Challanges in malaria research: Core science and innovation \\ Oxford, UK. 22-24 September 2014
}

\section{Background}

Ever since 2008, when evidence of artemisinin resistant malaria was highlighted in Western Cambodia [1], the need for new drugs with an original structure and novel mechanisms of action is even more pressing. The study of traditional remedies such as Cinchona bark or Artemisia aerial parts led to the discovery of the most potent antimalarials, bearing out that nature is still an incredible source of inspiration. Based on this approach, we are developing new synthetic antimalarial agents with an original structure inspired by nature.

\section{Material and methods}

In vitro antiplasmodial activity is evaluated against two strains of P. falciparum (multiresistant $\mathrm{K} 1$ and chloroquino-resistant 7G8) with two different methods: the inhibition of ${ }^{3}[\mathrm{H}]$-hypoxanthine incorporation assay and the Plasmodium-LDH immunoassay detection kit. Cytotoxicity assays are performed on two murine cell types (L6 and Hepa) in order to estimate the selectivity index, with two different viability tests: the resazurine assay and an MTTbased approach. In vivo activity is performed according to Peters' experiment [2] on P. berghei ANKA murine model at a dosing regimen of $100 \mathrm{mg} / \mathrm{kg}$ intraperitoneally.

\section{Results}

The isolation of an in vitro active biflavonoid from Campno-sperma panamense (Anacardiaceae, $\mathrm{IC}_{50}=480$ $\mathrm{nM}, P$. falciparum $\mathrm{K} 1$ ), led us to the development of simplified synthetic analogs (MR series) with improved pharmacological and pharmacokinetic profiles. Notably one of them (MR70) exhibits a partial in vivo antimalarial activity with a reduction of parasitaemia by $45 \%$ on day 4 .

\section{Conclusion}

We described here the first substituted flavone showing an in vivo antimalarial activity in a murine model. This scaffold should be promising in the fight against malaria. To understand its mechanism of action, we are currently running differential metabolomics analysis by solid NMR (coll. Pr. J. I. Namer, Strasbourg, France) to highlight some potential impact on Plasmodium metabolic pathways.

\section{Authors' details \\ 'Laboratoire d'Innovation Thérapeutique, Faculté de Pharmacie, UMR CNRS Unistra 7200, Illkirch, France. ${ }^{2}$ Faculté de Médecine, Institut de Parasitologie et de Pathologie Tropicale de Strasbourg, Strasbourg, France. ${ }^{3}$ Centre d'Etudes et de Recherches sur le Médicament en Normandie, Université de Caen Basse-Normandie, Caen, France. ${ }^{4}$ Swiss Tropical and Public Health Institute, Basel, Switzerland.}

Published: 22 September 2014

\section{References}

1. Noedl H, Se Y, Schaecher K, Smith BL, Socheat D, Fukuda MM: Evidence of artemisinin-resistant malaria in western Cambodia. N Engl J Med 2008, 359:2619-3620.

2. Peters W, Robinson BL: Handbook of animal models of infection: experimental models in antimicrobial chemotherapy. In Malaria Academic Press 1999, 757-773.

3. Weniger B, Vonthron-Sénécheau C, Arango GJ, Kaiser M, Brun R, Anton R: A bioactive biflavonoid from Campnosperma panamense. Fitoterapia 2004, 75:764-767.

\section{doi:10.1186/1475-2875-13-S1-P64}

Cite this article as: Nardella et al: Substituted flavones: a promising scaffold in the fight against malaria. Malaria Journal 2014 13(Suppl 1):P64. 